\title{
Factors inhibiting intestinal calcium absorption: hormones and luminal factors that prevent excessive calcium uptake
}

\author{
Kannikar Wongdee ${ }^{1,2} \cdot$ Mayuree Rodrat ${ }^{2,3} \cdot$ Jarinthorn Teerapornpuntakit ${ }^{2,4} \cdot$ Nateetip Krishnamra $^{2,3}$. \\ Narattaphol Charoenphandhu $u^{2,3,5,6}$
}

Received: 4 March 2019 / Accepted: 9 June 2019 / Published online: 20 June 2019

(c) The Physiological Society of Japan and Springer Japan KK, part of Springer Nature 2019

\begin{abstract}
Besides the two canonical calciotropic hormones, namely parathyroid hormone and 1,25-dihydroxyvitamin $\mathrm{D}\left[1,25(\mathrm{OH})_{2} \mathrm{D}_{3}\right]$, there are several other endocrine and paracrine factors, such as prolactin, estrogen, and insulin-like growth factor that have been known to directly stimulate intestinal calcium absorption. Generally, to maintain an optimal plasma calcium level, these positive regulators enhance calcium absorption, which is indirectly counterbalanced by a long-loop negative feedback mechanism, i.e., through calcium-sensing receptor in the parathyroid chief cells. However, several lines of recent evidence have revealed the presence of calcium absorption inhibitors present in the intestinal lumen and extracellular fluid in close vicinity to enterocytes, which could also directly compromise calcium absorption. For example, luminal iron, circulating fibroblast growth factor (FGF)-23, and stanniocalcin can decrease calcium absorption, thereby preventing excessive calcium uptake under certain conditions. Interestingly, the intestinal epithelial cells themselves could lower their rate of calcium uptake after exposure to high luminal calcium concentration, suggesting a presence of an ultra-short negative feedback loop independent of systemic hormones. The existence of neural regulation is also plausible but this requires more supporting evidence. In the present review, we elaborate on the physiological significance of these negative feedback regulators of calcium absorption, and provide evidence to show how our body can efficiently restrict a flood of calcium influx in order to maintain calcium homeostasis.
\end{abstract}

Keywords Calcium absorption · Calcium-sensing receptor (CaSR) - Fibroblast growth factor (FGF)-23 - Iron transport . Parathyroid hormone $(\mathrm{PTH}) \cdot$ Vitamin D

Narattaphol Charoenphandhu

naratt@narattsys.com

1 Faculty of Allied Health Sciences, Burapha University, Chonburi, Thailand

2 Center of Calcium and Bone Research (COCAB), Faculty of Science, Mahidol University, Bangkok, Thailand

3 Department of Physiology, Faculty of Science, Mahidol University, Rama VI Road, Bangkok 10400, Thailand

4 Department of Physiology, Faculty of Medical Science, Naresuan University, Phitsanulok, Thailand

5 Institute of Molecular Biosciences, Mahidol University, Nakhon Pathom, Thailand

6 The Academy of Science, The Royal Society of Thailand, Dusit, Bangkok, Thailand

\section{Introduction}

Besides being the major inorganic component in bone, calcium is an essential element that has roles in several functions, e.g., neurotransmitter release, muscle contraction, blood coagulation, and intracellular signal transduction. Ninety-nine percent of body calcium is stored in bone in the form of hydroxyapatite crystal $\left[\mathrm{Ca}_{10}\left(\mathrm{PO}_{4}\right)_{6}(\mathrm{OH})_{2}\right]$, while the remaining $1 \%$ is distributed in the plasma, interstitium, intracellular fluid, and within the cells in mitochondria and endoplasmic reticulum. The intracellular calcium is maintained at concentration as low as $0.1 \mu \mathrm{M}$, which is lower than the extracellular calcium concentration (free ionized calcium of 1.1-1.3 mM) by 1000-fold. An excess of calcium in either the intracellular or extracellular fluid is extremely dangerous. Because free ionized calcium is toxic to the cell, a prolonged rise in the intracellular calcium can lead to cell death by activating various enzymes, such as protein kinase 
$\mathrm{C}$, caspases, phospholipases, proteases, and endonucleases as well as apoptotic process [59]. Therefore, the intestine, which is the only site for calcium entry into the body, must have mechanisms to regulate calcium uptake. Besides, the intestinal epithelial cells themselves also need to tightly control their intracellular calcium concentration to prevent superfluous calcium uptake, which may damage themselves as well as other cells in the body $[57,59,106]$.

Since the intestine is the only route for calcium uptake, it is subjected to local and systemic regulation, which helps protect against inadequate as well as excessive absorption of calcium. Both stimuli and inhibitors of calcium absorption have been described, with the plasma calcium-PTH-vitamin D feedback loop as the most prominent feedback regulation. Although local hormones, secretory factors, and some components in the ingested foods, e.g., iron, phytate, oxalate, and tannin (Fig. 1), can inhibit calcium absorption, the physiological significance of these substances is not fully understood. The present article thus focuses on the regulatory roles of these intestine- and nutrientderived factors and their feedback mechanisms in the suppression of intestinal calcium absorption. It is generally accepted that both stimulatory and inhibitory regulators of calcium absorption are humoral factors with autocrine, paracrine, and endocrine functions, as depicted in Fig. 1. Apparently, the possible role of neural regulation may also exist and may be analogous to the splanchnic nerve regulation of calcium uptake across the gallbladder mucosa [73]. The overview of factors controlling intestinal calcium transport is summarized in Table 1.

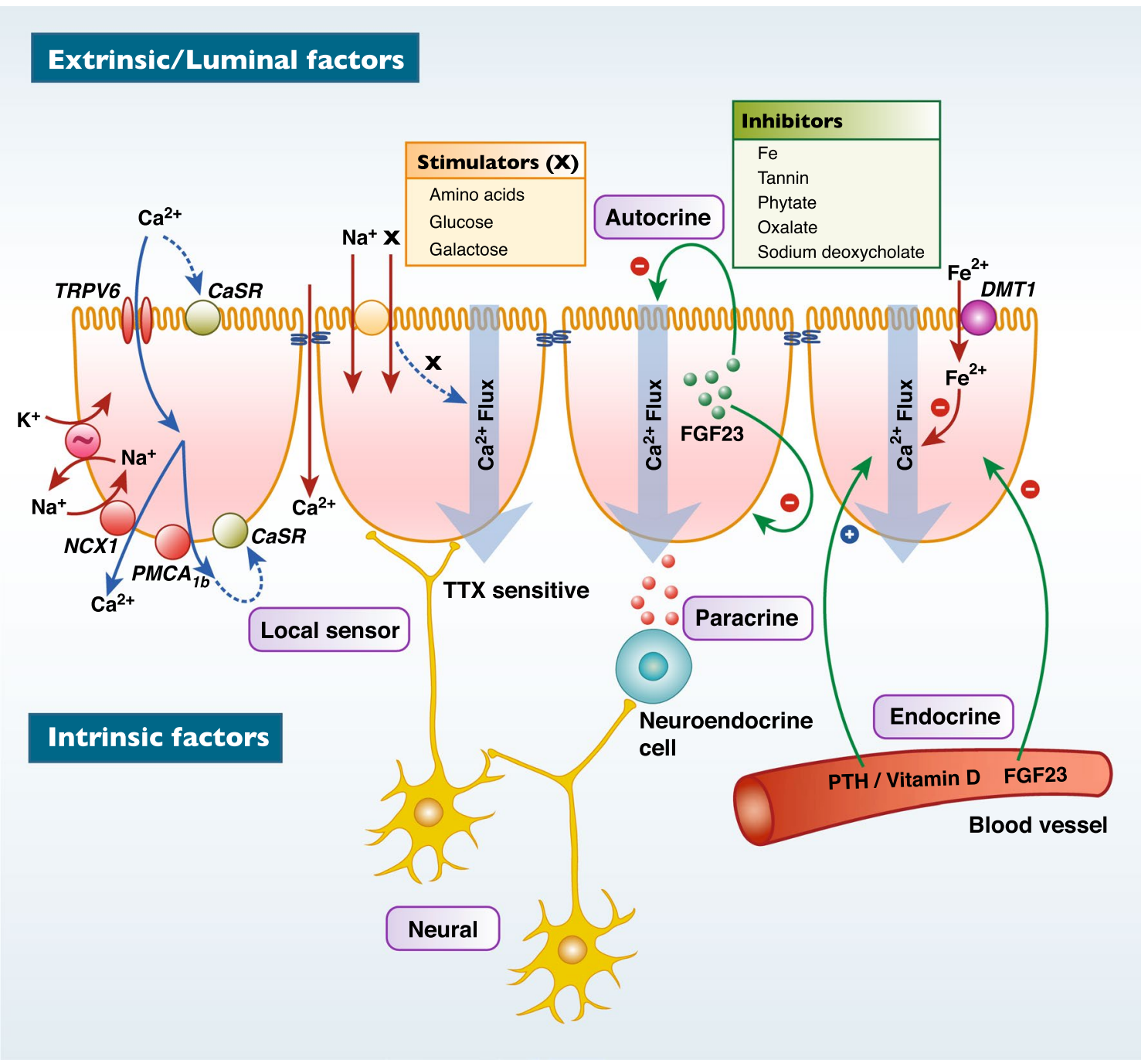

Fig. 1 Intrinsic (humoral and neural) and extrinsic (luminal) regulators of intestinal calcium absorption (please see text for details) 
Table 1 Summary of possible factors affecting calcium absorption across the intestinal epithelium

\begin{tabular}{|c|c|c|c|c|}
\hline Factors & Transcellular & Paracellular & Net $\mathrm{Ca}^{2+}$ absorption & References \\
\hline \multicolumn{5}{|l|}{ Extrinsic/luminal } \\
\hline $\begin{array}{l}\mathrm{Ca}^{2+} \text { (long-term low luminal } \\
\left.\mathrm{Ca}^{2+} \text { or low calcium diet }\right)\end{array}$ & $\begin{array}{l}\text { Increase expression of TRPV5/6, } \\
\text { CaBP-D } \mathrm{D}_{9 \mathrm{k}}, \mathrm{NCX} 1, \mathrm{PMCA}_{1 \mathrm{~b}} \text {, } \\
\text { Increase activity of } \mathrm{PMCA}_{1 \mathrm{~b}} \text { and } \\
\text { NCX1 }\end{array}$ & N/A & $\uparrow$ & {$[4,8,10]$} \\
\hline $\begin{array}{l}\mathrm{Ca}^{2+} \text { (prolong exposure to high } \\
\text { luminal } \mathrm{Ca}^{2+} \text { ) }\end{array}$ & $\begin{array}{l}\text { Possibly by increase FGF-23 } \\
\text { expression }\left(\mathrm{Ca}^{2+}>30 \mathrm{mM}\right) \text { and } \\
\text { inhibit transcellular transport by } \\
\text { unknown mechanism }\end{array}$ & N/A & $\downarrow$ & {$[84]$} \\
\hline Iron & N/A & N/A & $\downarrow$ & {$[58]$} \\
\hline $\begin{array}{l}\text { Glucose/galactose (SGLT1 } \\
\text { substrates) }\end{array}$ & Decrease $\mathrm{Ca}_{\mathrm{v}} 1.3$ activity & $\begin{array}{l}\text { Increase solvent drag-induced } \\
\text { paracellular calcium flow }\end{array}$ & $\uparrow$ & {$[52,91]$} \\
\hline Amino acids & N/A & $\begin{array}{l}\text { Increase NHE activity } \\
\text { Increase nutrient-induced paracel- } \\
\text { lular calcium flow }\end{array}$ & $\uparrow$ & [96] \\
\hline Fructose & $\begin{array}{l}\text { Decrease expression of TRPV6 and } \\
\text { CaBP-D }{ }_{9 \mathrm{k}}\end{array}$ & N/A & $\downarrow$ & {$[27,28]$} \\
\hline \multicolumn{5}{|l|}{ Intrinsic } \\
\hline \multicolumn{5}{|l|}{ Hormone } \\
\hline $1,25(\mathrm{OH})_{2} \mathrm{D}_{3}$ & $\begin{array}{l}\text { Increase expression of TRPV5/6, } \\
\text { CaBP-D }_{9 \mathrm{k}}, \mathrm{NCX}_{1}, \mathrm{PMCA}_{1 \mathrm{~b}}\end{array}$ & $\begin{array}{l}\text { Stimulate nongenomic signaling } \\
\text { pathways involving PI3K, PKC, } \\
\text { and MEK to enhance calcium } \\
\text { transport } \\
\text { Increase expression of claudin- } 2 \text {, } \\
12\end{array}$ & $\uparrow$ & {$[32,40]$} \\
\hline PTH & $\begin{array}{l}\text { Increase calcium uptake } \\
\text { (Unknown mechanism) }\end{array}$ & N/A & $\uparrow$ & [71] \\
\hline FGF-23 & $\begin{array}{l}\text { Decrease } 1,25(\mathrm{OH})_{2} \mathrm{D}_{3} \text {-enhanced } \\
\text { expressions of TRPV5/6, CaBP- } \\
\mathrm{D}_{9 \mathrm{k}}\end{array}$ & $\begin{array}{l}\text { Decrease } 1,25(\mathrm{OH})_{2} \mathrm{D}_{3} \text {-enhanced } \\
\text { paracellular calcium transport } \\
\text { and calcium permeability }\end{array}$ & $\downarrow$ & {$[53,54]$} \\
\hline \multicolumn{5}{|l|}{ Paracrine } \\
\hline FGF-23 & Increase CaSR activity & N/A & $\downarrow$ & [84] \\
\hline Stanniocalcin-1 & $\begin{array}{l}\text { Decrease expression of TRPV } 5 / 6 \text {, } \\
\text { CaBP-D } \text { D }_{9 \mathrm{k}} \\
\text { No change in the expression of } \\
\text { NCX1, PMCA }{ }_{1 b}\end{array}$ & N/A & $\downarrow$ & {$[107]$} \\
\hline \multicolumn{5}{|l|}{ Neural (ENS) } \\
\hline VIP & N/A & N/A & $\begin{array}{l}\uparrow \\
\text { (Indirect evidence) }\end{array}$ & [73] \\
\hline
\end{tabular}

$C a B P-D_{9 k}$ calbindin- $D_{9 \mathrm{k}}, C a S R$ calcium-sensing receptor, $C a_{v} 1.3$ L-type voltage-gated calcium channel, $F G F$-23 fibroblast growth factor 23 , $E N S$ enteric nervous system, NIA not available, NCX1 sodium calcium exchanger 1, TJ tight junction, VIP vasoactive intestinal peptide

\section{Mechanisms of intestinal calcium absorption in mammals}

In mammals, calcium is absorbed through the intestinal epithelial cells via two major pathways, i.e., transcellular and paracellular pathways [24]. The relative contribution of transcellular and paracellular calcium absorption depends on several factors including the amount of calcium intake, solubility and chyme alkalinity, bioavailability, and segment transit time [52]. Although both calcium transport mechanisms are found along the entire length of the intestine in humans and rodents, the vitamin D-dependent transcellular calcium transport is predominant in the proximal small intestine, particularly the duodenum, and is of importance in low-calcium intake conditions [3, 7, 103]. A regular diet without dairy products is generally considered as a low-normal calcium diet, which requires an active calcium transport mechanism.

The uphill transcellular active transport is composed of three steps, i.e., (1) apical vitamin D-dependent calcium entry via the transient receptor potential cation channel, subfamily V, member 6 (TRPV6), and to a lesser extent 
TRPV5, (2) cytoplasmic calcium translocation (bound to calbindin- $\mathrm{D}_{9 \mathrm{k}}$ ), and (3) basolateral calcium extrusion via plasma membrane $\mathrm{Ca}^{2+}$-ATPase $1 \mathrm{~b}\left(\mathrm{PMCA}_{1 \mathrm{~b}}\right)$ and $\mathrm{Na}^{+} /$ $\mathrm{Ca}^{2+}$-exchanger 1 (NCX1) $[13,24]$. Regarding calcium entry into the enterocytes, besides TRPV5/6 channels, the apical voltage-dependent L-type calcium channel subtype $1.3\left(\mathrm{Ca}_{\mathrm{v}} 1.3\right)$ is also involved in calcium uptake, particularly in the presence of depolarizing nutrients in the lumen, such as glucose, galactose, and some amino acids [52, 68, 96].

Once calcium enters the cells, it is buffered by the cytoplasmic calcium-binding protein, calbindin- $\mathrm{D}_{9 \mathrm{k}}[24,86]$. Other calcium-binding proteins such as calmodulin may also contribute, albeit to a lesser extent, to the intracellular calcium translocation [24]. Finally, calcium is extruded across the basolateral membrane through several transporters, e.g., PMCA $_{1 \mathrm{~b}}, \mathrm{NCX} 1$ coupled to $\mathrm{Na}^{+} / \mathrm{K}^{+}$-ATPase, and $\mathrm{Na}^{+} / \mathrm{Ca}^{2+} /$ $\mathrm{K}^{+}$-exchanger (NCKX), the latter of which extrudes one $\mathrm{K}^{+}$ and one $\mathrm{Ca}^{2+}$ with influx of four sodium ions to maintain low intracellular calcium concentration [52, 57, 88].

The second major route is the paracellular pathway, which allows calcium to traverse the lateral intercellular (paracellular) space. Calcium transport via this route can be both cellular energy-dependent active or gradient-dependent passive transport. The paracellular active transport is generally mediated by solvent drag, which is induced by sodium efflux by $\mathrm{Na}^{+} / \mathrm{K}^{+}$-ATPase that creates hyperosmotic environment in the paracellular space. This subsequently induces water diffusion in a lumen-to-plasma direction, dragging along with it small permeable molecules, including calcium [6, 24, 52].

Regarding the paracellular passive calcium transport driven by the concentration gradient of calcium between the lumen and plasma, it occurs more readily in the condition of high-calcium intake-generally considered significant when luminal calcium $>5 \mathrm{mM}$ - and can occur throughout the entire length of the intestine [24, 30]. Paracellular transport is also determined notably by the size- and charge-selective properties of the tight junction, which creates specific barriers for ions, such as calcium, sodium, and chloride [112]. Claudins is the major family of the tight junction-associated proteins responsible for the paracellular size- and chargeselective properties. Claudin-2, -12 , and -15 in particular have been shown to have significant roles in the regulation of paracellular calcium transport across the intestinal epithelia [14, 24, 32]. Claudin-2 has negatively charged amino acids (e.g., aspartate) in the extracellular domains, which protrude into the paracellular space to form a tight junction pore. With these negative charges, claudin- 2 is permeable to cations $[21,110]$. In the presence of upregulated claudin-2 expression, the luminal calcium is expected to easily diffuse across the paracellular space in both lumen-to-plasma and plasma-to-lumen directions. When the luminal concentration is greater than the plasma ionized calcium level (e.g., luminal calcium $>5 \mathrm{mM}$ ), calcium prefers to diffuse into the body. On the other hand, an extremely low calcium concentration in the lumen may aggravate calcium secretion, which probably results in net calcium loss during claudin-2 overexpression. However, further experiment is required to confirm the latter hypothesis.

\section{Possible feedback loops for intestinal calcium absorption}

To maintain calcium homeostasis, the amount of calcium absorbed by the intestine is fine-tuned to match the body calcium requirement by several factors, including hormones and luminal nutrients [57]. Since calcium absorption is relatively low under normal conditions $(\sim 25-35 \%$ of total calcium intake) as compared with other minerals (such as magnesium and phosphorus), most regulatory factors are stimulators for enhancing calcium absorption. However, little is known regarding how calcium absorption is regulated when faced with excessive calcium intake and a potential risk of calcium toxicity. Normally, the level of plasma calcium is considered as a component of the negative feedback regulation to suppress parathyroid hormone (PTH) release and production of 1,25-dihydroxycholecalciferol $\left[1,25(\mathrm{OH})_{2} \mathrm{D}_{3}\right]$, thereby slowing down the intestinal calcium absorption as discussed below.

\section{Roles of hormones}

The classical hormones involved in the positive regulation of intestinal calcium absorption are PTH and $1,25(\mathrm{OH})_{2} \mathrm{D}_{3}$, the latter of which is synthesized in the kidney by the renal proximal tubule and which directly enhances the intestinal calcium absorption through active transcellular and passive paracellular pathways in both genomic and non-genomic fashion (for review, please see Ref. [57]). For the active transcellular pathway, $1,25(\mathrm{OH})_{2} \mathrm{D}_{3}$ exerts genomic actions by binding to vitamin D receptor (VDR), thus increasing the expression of calcium transport machinery, i.e., TRPV6, calbindin$\mathrm{D}_{9 \mathrm{k}}, \mathrm{PMCA}_{1 \mathrm{~b}}$, and NCX1 [11, 20, 24, 104]. In addition, $1,25(\mathrm{OH})_{2} \mathrm{D}_{3}$ probably exerts a non-genomic action to rapidly enhance calcium transport by binding to the plasma membrane receptor $1,25(\mathrm{OH})_{2} \mathrm{D}_{3}$-MARRS (membrane-associated, rapid response steroid-binding) protein [72]. In brief, the non-genomic action occurs when $1,25(\mathrm{OH})_{2} \mathrm{D}_{3}$ binds to the membrane-bound $1,25(\mathrm{OH})_{2} \mathrm{D}_{3}$ MARRS instead of the intracellular/nuclear VDR, which is a transcription factor [29]. This membrane-bound receptor can activate certain second messengers, including phospholipase A2 (PLA2) and protein kinase C (PKC) $[26,87]$. Regarding the paracellular absorption, 
$1,25(\mathrm{OH})_{2} \mathrm{D}_{3}$ enhances calcium transport through both passive diffusion and solvent drag mechanisms, in part by modifying the charge- and size-selective properties of the tight junction proteins, particularly claudin- 2 and -12 [32].

PTH is widely known as a hypercalcemic and hypophosphatemic hormone upstream to $1,25(\mathrm{OH})_{2} \mathrm{D}_{3}$. It elevates the plasma calcium levels by enhancing osteoclastic bone resorption, renal calcium reabsorption, and increasing intestinal calcium uptake [37]. However, the role of PTH on intestinal calcium absorption is normally indirect through renal $1,25(\mathrm{OH})_{2} \mathrm{D}_{3}$ production. Specifically, PTH stimulates the transcription of the CYP27B1 gene for renal enzyme $1 \alpha$-hydroxylase, and suppresses CYP24A1 for renal 24-hydroxylase, an enzyme responsible for $1,25(\mathrm{OH})_{2} \mathrm{D}_{3}$ degradation [111], thus elevating the plasma level of $1,25(\mathrm{OH})_{2} \mathrm{D}_{3}$. For the direct action of PTH on the intestinal calcium absorption, it was reported that $N$-terminal fragment $1-34$ of PTH could stimulate calcium transport in perfused duodenal loops from normal chicks transcaltachia (rapid, non-genomic)—a rapid hormonal stimulation of intestinal calcium absorption [71, 75]. Moreover, the presence of PTH receptor 1 (PTH1R) in the basolateral membrane of rat intestinal epithelial cells suggests possible direct action of PTH in the intestine. However, this study did not demonstrate the regulation of PTH on intestinal calcium absorption [36]. Indeed, direct exposure to PTH not only increases calcium absorption but also promotes transport of other ions, e.g., potassium, chloride, and bicarbonate, across the intestinal epithelium. There was evidence that PTH regulation of bicarbonate secretion is not an adaptive mechanism but is more like transcaltachia (rapid, non-genomic). These studies used Caco- 2 cells, which may reflect a colonic phenotype unless the results are confirmed in small intestine [16, 61]. Up till now, the physiological significance of the PTH-regulated ion transport in the gut is not clearly known.

Another hormone that was recently shown to have a calcium-regulating function is the bone-derived fibroblast growth factor (FGF)-23 [53, 54, 79]. FGF-23 was generally recognized as a phosphaturic hormone produced and secreted from osteocytes and osteoblasts. Its secretion is enhanced by high serum phosphate, $1,25(\mathrm{OH})_{2} \mathrm{D}_{3}$, and perhaps calcium $[64,79,100]$. The systemic actions of FGF-23 are to increase urinary phosphate excretion and suppress $1,25(\mathrm{OH})_{2} \mathrm{D}_{3}$ production. FGF-23 suppresses CYP27B1 gene expression and stimulates $C Y P 24 A 1$ gene expression, leading to a decreased circulating $1,25(\mathrm{OH})_{2} \mathrm{D}_{3}$ $[78,89]$. Furthermore, FGF-23 has recently been shown to act directly on the intestine to abolish the $1,25(\mathrm{OH})_{2} \mathrm{D}_{3}$ stimulated intestinal calcium absorption [53, 54]. The cellular mechanism of FGF-23 as a local inhibitor of calcium absorption is elaborated in "intrinsic inhibitory factors".

\section{Roles of calcium-sensing receptor (CaSR)}

Parathyroid chief cells, renal tubular cells, and osteoblasts are known to express CaSR for sensing pericellular calcium. Normally, CaSR also senses other positively charged ions (e.g., $\mathrm{Mg}^{2+}, \mathrm{Cd}^{2+}, \mathrm{Ba}^{2+}, \mathrm{La}^{3+}$ and $\mathrm{Gd}^{3+}$ ), cationic molecules (e.g., $\gamma$-glutathione), and amino acids and polyamines (e.g., tryptophan, L-phenylalanine, spermidine, and spermine) [12, $22]$. Thus, an increase in plasma calcium level is detectable by parathyroid chief cells, resulting in an inhibition of PTH release and decrease in calcium absorption (Fig. 2a). However, up until now, the role of CaSR in the intestinal epithelial cells has been elusive, and whether it can directly modulate intestinal calcium absorption independent of PTH is largely unknown. Indeed, CaSR may potentially play a role in local regulation of intestinal calcium absorption since it is abundantly expressed in both apical and basolateral membranes of the enterocytes [17]. However, most studies on the intestinal CaSR have been performed in the large intestine rather than the small intestine where calcium absorption is most active [5, 18, 41]. Direct activation of this receptor in the apical membrane can increase calcium absorption in the large intestine $[18,50]$, while reducing calcium uptake in the small intestinal-like Caco-2 monolayer (Fig. 2b). Rodrat et al. have reported that CaSR probably sensed high apical calcium which in turn increased FGF-23 expression to suppress calcium transport [84]. The roles of intestinal CaSR were also studied in Casr intestinal-specific knockout mice. Although Casr-deficient mice manifested an impaired intestinal integrity, altered composition of the gut microbiota and inflammation [19,77], the function related to the regulation of calcium transport was not determined.

Similarly, the renal tubular epithelia also use local CaSR to modulate calcium reabsorption. Activation of CaSR on the luminal side of renal proximal tubular cells is capable of stimulating $\mathrm{Na}^{+} / \mathrm{H}^{+}$-exchanger 3 (NHE3), thereby enhancing the paracellular calcium transport via a solvent dragmediated mechanism (Fig. 2c) [101]. On the other hand, the basolateral CaSR plays a role in the inhibition of the paracellular calcium reabsorption in the thick ascending limb of Henle's loop independent of PTH action [98].

\section{Stimulation of intestinal calcium absorption by luminal nutrients}

It has also been reported that a number of nutrients, including amino acids, oligosaccharides, disaccharides, and monosaccharides (glucose and galactose), can stimulate calcium absorption [91, 92, 96, 109], however, it remains largely unknown how this process is counterbalanced. Generally, there are at least three possible mechanisms to explain how the enterocytes enhance calcium transport in response to 
Fig. 2 Responses of calciumsensing receptor (CaSR) to extracellular calcium in a parathyroid chief cells, b intestinal epithelial cells, and $\mathbf{c}$ renal tubular epithelial cells (please see text for details)
A

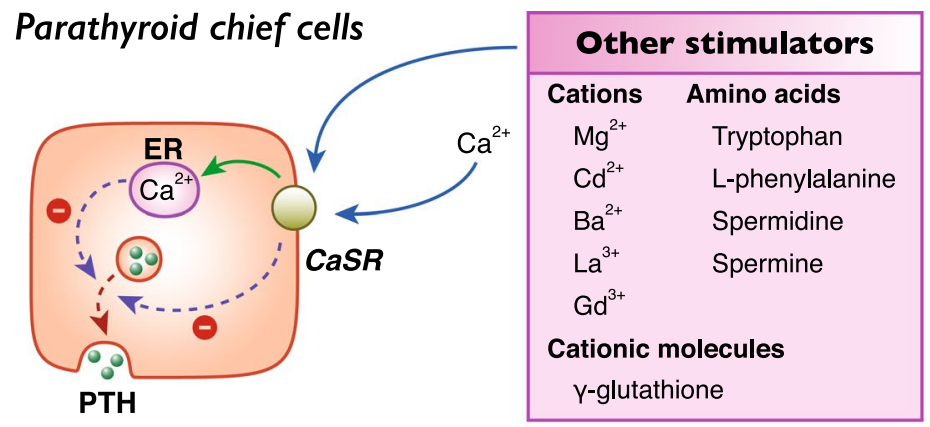

B

Intestinal epithelial cells

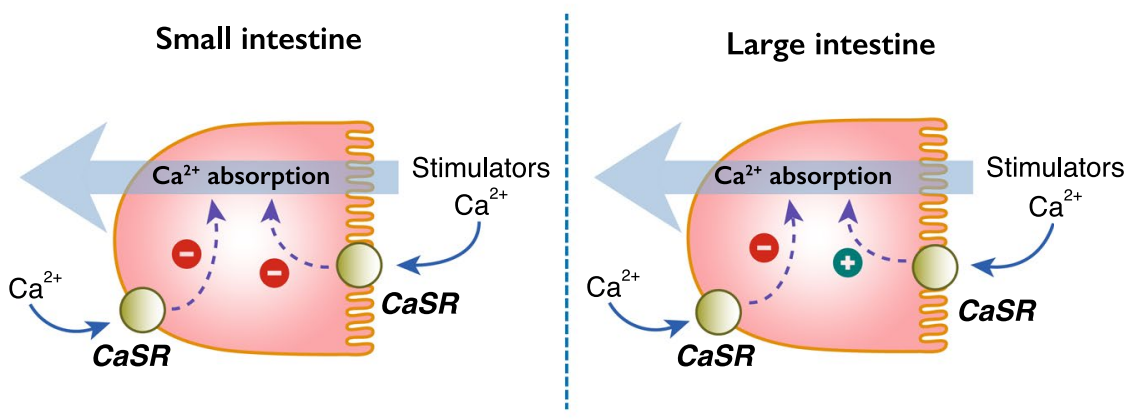

C

Renal tubular epithelial cells
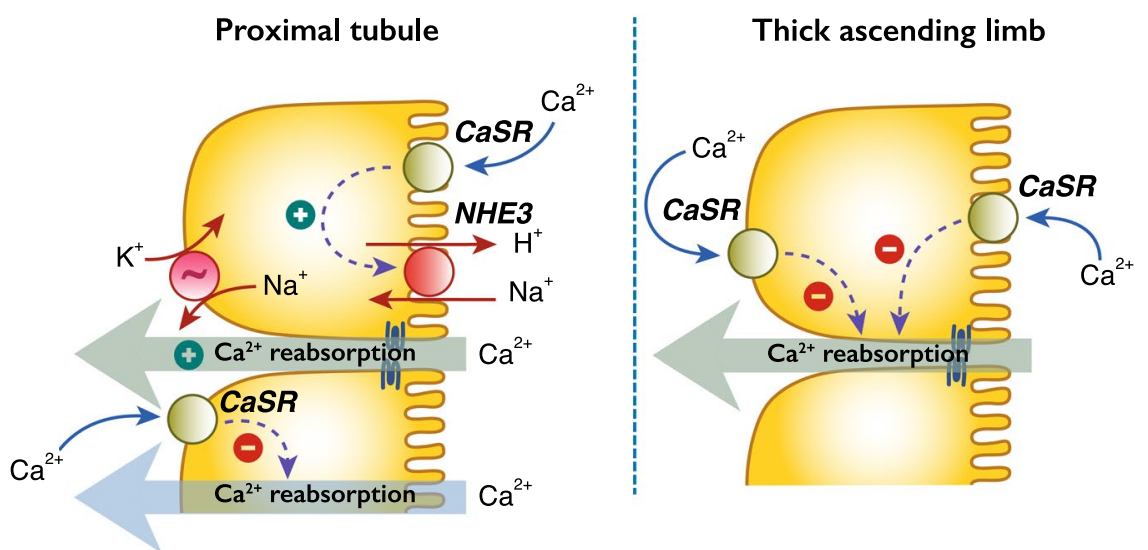

luminal nutrients, i.e., nutrient-induced paracellular calcium flow, $\mathrm{Ca}_{\mathrm{v}} 1.3$ activation, and NHE3 activation.

\section{Solvent drag and nutrient-induced paracellular calcium flow}

Glucose and/or galactose enter the intestinal cells via apical sodium-dependent glucose transporter-1 (SGLT1), after which sodium is pumped out into the paracellular space by $\mathrm{Na}^{+} / \mathrm{K}^{+}$-ATPase especially those at the lateral membrane. As explained earlier, the increase in the paracellular osmolality together with relative permeability of tight junction to water drives paracellular water flow from luminal to the blood side, bringing calcium with it.
Therefore, this calcium transport is referred to as the solvent drag-induced calcium absorption [52, 91]. In addition, the fermented dairy products and incomplete digested carbohydrate, e.g., short-chain fatty acid, oligosaccharides, and polysaccharides, can also enhance calcium absorption in the small and large intestine in rats by increasing tight junction permeability to calcium $[80,108]$. Although the solvent drag was not directly determined in most studies, the solvent drag-induced paracellular calcium transport should contribute to the process since the uptake of these small organic molecules is often sodium-dependent. However, the direct effect of microbiota-derived organic molecules on the transcellular calcium transporters cannot be ruled out and requires future investigation. 


\section{$\mathrm{Ca}_{\mathrm{v}} 1.3$ activation}

Under normal conditions, the resting membrane potential of the intestinal epithelial cells is approximately $-47 \mathrm{mV}$. Influx of sodium together with glucose can depolarize the apical membrane, thereby activating $\mathrm{Ca}_{\mathrm{v}} 1.3$ for transcellular calcium uptake particularly when the transmembrane potential reaches the $\mathrm{Ca}_{\mathrm{v}} 1.3$ threshold of approximately $-20 \mathrm{mV}$ [52]. Lactose - the major disaccharide in milk-also stimulates intestinal calcium absorption [1], but the mechanism remains unclear. It is possible that the effect of lactose is due to the elevated concentrations of glucose and galactose following lactose digestion by lactase in the intestinal lumen. Both glucose and galactose are substrates of SGLT1, which can induce sodium entry, thereby depolarizing the apical plasma membrane and activating apical calcium channel, $\mathrm{Ca}_{\mathrm{v}} 1.3$, for calcium to diffuse down its concentration gradient into the cell [52].

\section{NHE3 activation}

Although some amino acids are transported by sodiumdependent amino acid transporter (e.g., $\mathrm{B}^{0} \mathrm{AT} 1$ ) similar to monosaccharide absorption by SGLT1 [47], oligopeptides are taken up into the enterocytes by $\mathrm{H}^{+}$-coupled peptide transporter (PepT1) [102]. It is possible that $\mathrm{H}^{+}$is extruded from the cell back into the lumen via NHE3, allowing only sodium to enter the cell down its concentration gradient and to exit the cell by the basolateral $\mathrm{Na}^{+} / \mathrm{K}^{+}$-ATPase into the paracellular space, thus generating solvent drag along the paracellular space.

The exact mechanism by which NHE3 modulates calcium absorption is largely unknown, but the NHE3 inhibitor, tenapanor, was found to completely abolish intestinal calcium transport [96]. Interestingly, NHE3 not only acts as a carrier for sodium uptake but also plays an important role in the regulation of intestinal $\mathrm{pH}$. Apical NHE3 transports $\mathrm{H}^{+}$into the lumen in exchange with $\mathrm{Na}^{+}$, thus preventing intracellular acidification, and at the same time making the lumen more acid, which is known as acid microclimate [97]. A slight luminal acidification promotes the generation of ionized calcium, which might subsequently increase calcium absorption [31]. NHE3 knockout animals were found to have impaired absorption of calcium, sodium, and water, as well as acid/base imbalance [74, 81]. This finding could be partially explained by the fact that NHE3 normally transports $\mathrm{H}^{+}$to the lumen while uptaking $\mathrm{Na}^{+}$into the cytoplasm. A reduction in the transcellular calcium absorption in NHE3 null mice was mainly due to a decrease in calcium flux in mucosal-to-serosal direction, consistent with the downregulation of TRPV6 expression [81].

\section{Counterregulatory and inhibitory factors for intestinal calcium absorption}

Although the body has a calcium-lowering hormone, calcitonin, and the kidney to prevent hypercalcemia through suppression of bone resorption and enhancement of urinary calcium excretion, respectively. These mechanisms take place only after calcium has already been taken up into the body and raise its plasma concentration. It is tempting to postulate that the intestine as a front line to encounter calcium has a monitoring mechanism to prevent flooding of calcium into the enterocytes. Several lines of evidence have suggested the presence of counterregulatory or inhibitory factors for limiting calcium absorption, e.g., hormones, luminal ions, or byproduct of nutrient digestion $[9,60]$. In this review, we subdivide these counterregulatory factors into two major groups, i.e., factors in the lumen (extrinsic) and those in the plasma (intrinsic), as shown in Fig. 1.

\section{Extrinsic inhibitory factors}

The extrinsic or luminal factors are defined as luminal content-derived factors that may be either nutrient or non-nutrient substances with inhibitory effect on calcium absorption, e.g., high luminal calcium concentration, iron, sugars, and byproducts of nutrient digestion (e.g., phytate, oxalate, and tannin), as follows.

\section{Prolonged exposure to high luminal calcium}

Previously, calcium has been known to exert indirect negative feedback on calcium absorption. Briefly, CaSR has been reported in the apical and basolateral plasma membrane [17, 18]. It is postulated that CaSR exerts its signaling through activation of phosphodiesterases (PDE) which in turn enhances cyclic nucleotide degradation [35, 94]. Although information on specific PDE in the intestinal epithelial cells is scant, PDE might be an important mediator in the negative regulatory process because of the existence of PDE1-5 isoforms in human colonic cancer cells [76, 94].

Interestingly, Rodrat et al. [84] recently demonstrated that transepithelial calcium transport across Caco-2 monolayer was diminished after direct exposure to high-dose $1,25(\mathrm{OH})_{2} \mathrm{D}_{3}(10 \mathrm{nM})$ or high concentration of apical ionized calcium ( $30 \mathrm{mM} \mathrm{CaCl}_{2}$ ). Since CaSR inhibitors (calhex 231 and NPS2143) could prevent the high luminal calciuminduced suppression of calcium transport, it is likely that apical CaSR acts as a component of an anticipatory or feedback mechanism to prevent excessive calcium influx into the cell, while CaSR in the basolateral membrane probably helps detect the amount of absorbed calcium ions that accumulate in the immediate vicinity of the basal membrane or 
paracellular space. In other words, the intestinal epithelial cells are able to closely monitor ionized calcium levels at both entry and exit points by using CaSR which in turn activates secondary negative regulators, e.g., FGF-23, to slow down calcium absorption, thus preventing excessive calcium uptake into the body $[53,54,84]$. Detail of the inhibitory effect of FGF23 is further described in the following section.

\section{Iron}

It has long been known that high oral calcium intake interferes with heme and nonheme iron absorption [63, 76], but whether high iron intake causes a reduction in calcium absorption is still uncertain. A recent investigation in iron hyperabsorptive $\beta$-thalassemic mice showed that duodenal calcium absorption had an inverse correlation with transepithelial iron transport [58]. Interestingly, after injection of hepcidin-a liver-derived inhibitory factor of intestinal iron absorption [38] - the thalassemia-induced impairment of calcium absorption was alleviated [58]. However, the exact cellular and molecular mechanisms of iron-associated impairment of calcium absorption require further investigation.

\section{Sugars}

Although some monosaccharides, particularly SGLT1 substrates (e.g., glucose and galactose) stimulate intestinal calcium absorption, a ketonic monosaccharide fructose found in fruits, vegetables, and grains can produce an inhibitory effect $[28,85]$. Both in vitro and in vivo studies revealed that fructose diminished intestinal calcium absorption, in part by reducing circulating $1,25(\mathrm{OH})_{2} \mathrm{D}_{3}$ levels, TRPV6 and calbindin- $\mathrm{D}_{9 \mathrm{~K}}$ expression, and thus transcellular calcium transport [28]. Furthermore, high fructose intake was found to diminish calcium absorption in growing and lactating rats through disrupting $1,25(\mathrm{OH})_{2} \mathrm{D}_{3}$ metabolism, i.e., enhancing $1,25(\mathrm{OH})_{2} \mathrm{D}_{3}$ catabolism and impairing $1,25(\mathrm{OH})_{2} \mathrm{D}_{3}$ synthesis $[27,28]$.

\section{Natural substances and byproducts of nutrient digestion}

A number of naturally occurring substances in many green leafy vegetables (e.g., spinach, beet greens, and tea), for example, oxalate, phytate, and tannin, can block the intestinal calcium absorption by binding to calcium, thereby rendering calcium insoluble and unavailable for absorption [2, 69]. However, their physiological significance and the final effect on calcium absorption remain controversial. For example, calcium bioavailability of green leafy vegetables such as centella, quinoa, and roselle, all of which contain high amounts of inhibitory factors, was not changed by cooking process or phytase digestion [2,69]. On the other hand,
Nigerian children fed phytase-treated or untreated meal showed no difference in their fractional calcium absorption [95]. Nevertheless, a correlation analysis on calcium and inhibitory factors, including oxalate, tannin, phytate, and dietary fiber revealed that oxalate had the greatest negative effect on calcium bioavailability [2].

Besides nutrient and non-nutrient substances, other luminal compounds can inhibit calcium absorption, for instance, lithocholic acid (LCA), deoxycholic acid or its salt, sodium deoxycholate (NaDOC). LCA and NaDOC are secondary bile acids that are formed by enzymes of the intestinal flora. A high concentration of NaDOC not only damages liver tissue and promotes colon cancer [92], but also impairs intestinal calcium absorption [46, 66, 83]. Determination of calcium absorption in chick duodenum revealed that NaDOC suppressed calcium absorption by downregulating transcellular calcium transport machinery, i.e., $\mathrm{PMCA}_{1 \mathrm{~b}}$, calbindin- $\mathrm{D}_{28 \mathrm{k}}$, and NCX1. Such negative effects might be a consequence of oxidative stress as suggested by concurrent increases reactive oxygen species (ROS) production, glutathione reduction, and mitochondrial swelling. Indeed, ROS has been shown to inhibit calcium absorption [83]. More studies are required to show if NaDOC-induced impaired intestinal calcium absorption would be of clinical concern on bone health.

\section{Intrinsic inhibitory factors}

Intestinal calcium absorption can be affected by humoral agents acting from the serosal side. Although calcitonin is known as a hypocalcemic hormone, it does not have any direct action on the intestinal epithelial cells. It induces hypocalcemia mainly by inhibiting osteoclast-mediated bone resorption and enhancing renal calcium excretion [57]. So the importance of calcitonin in the day-to-day calcium homeostasis is negligible. Recently, bone-derived FGF-23 was proposed as a novel inhibitory regulator of intestinal calcium absorption [53, 54, 105].

\section{FGF-23}

In general, calcium in the plasma is the major factor moderate the intestinal calcium absorption through the long loop negative feedback by inhibiting PTH production and release. Specifically, a slight increase in the plasma-free ionized calcium leads to activation of CaSR in the parathyroid chief cells [82], thereby reducing PTH release. A reduction in serum PTH results in decreases in the circulating $1,25(\mathrm{OH})_{2} \mathrm{D}_{3}$ level and finally the intestinal calcium absorption. However, some factors can also reduce the plasma calcium by acting at the absorption site.

As mentioned earlier, FGF-23 is primarily known as a bone-derived phosphaturic hormone that mainly enhances 
renal phosphate excretion and $1,25(\mathrm{OH})_{2} \mathrm{D}_{3}$ catabolism [39, 51]. Besides being produced by bone cells, it is also abundantly expressed in other cells, such as kidney, brain, lung, liver, spleen, and intestinal enterocytes $[53,56]$. Normally, an increase in serum phosphate stimulates the secretion of PTH and FGF-23, both of which enhance urinary phosphate excretion to prevent undesirable clinical problems due to hyperphosphatemic spikes, such as ectopic calcification [43, 49]. FGF-23 enhances phosphate excretion directly through inactivation of sodium/phosphate cotransporter (NaPi)-2a and $-2 \mathrm{c}$ in the proximal renal tubules and indirectly by suppressing $1,25(\mathrm{OH})_{2} \mathrm{D}_{3}$ synthesis and promoting $1,25(\mathrm{OH})_{2} \mathrm{D}_{3}$ conversion to inactive $24,25(\mathrm{OH})_{2} \mathrm{D}_{3}$, thereby reducing the circulating $1,25(\mathrm{OH})_{2} \mathrm{D}_{3}$ levels and also intestinal phosphate $[51,56,90]$. These complete the negative feedback loop for phosphorus homeostasis.

However, an experiment in VDR knockout mice suggested that elevation of plasma calcium was a potent stimulator of FGF-23 production in a VDR-independent manner [90]. Later evidence supported the notion that FGF-23 not only controls phosphorus metabolism but also acts as a calcium-regulating hormone that directly controls the intestinal calcium absorption through both systemic and local (paracrine) mechanisms. The systemic effect was demonstrated by complete abolishment of $1,25(\mathrm{OH})_{2} \mathrm{D}_{3}$-enhanced duodenal calcium transport by intravenous FGF-23 injection [53]. Furthermore, the finding that FGF-23 in the intestine, ex vivo studies in murine duodenum demonstrated that FGF-23 directly diminished the $1,25(\mathrm{OH})_{2} \mathrm{D}_{3}$-enhanced transcellular and paracellular calcium absorption in ex vivo murine duodenum evinced that FGF-23 could exert direct action on the intestine [53, 54]. Moreover, other studies reported that FGF receptors (FGFRs) express in both small and large intestinal cells $[70,93,105]$. These findings confirmed that FGF-23 may have direct actions on the intestinal cells. Although there were a number of reports in $\mathrm{Fgfr}^{-/-}, \mathrm{Fgfr}^{-/-}$, and $\mathrm{Fgfr}^{-/-}$mice [33, 34], the intestinal calcium flux in FGFRs knockout animals has never been investigated.

Interestingly, FGF-23 not only elicits action from the basolateral side but also exerts a negative feedback regulation on calcium transport across the Caco-2 monolayer from the apical side [84], consistent with the presence of FGF receptors in both apical and basolateral membranes of the duodenal enterocytes [53]. The expression of FGF-23 protein in the enterocytes is upregulated by $1,25(\mathrm{OH})_{2} \mathrm{D}_{3}$ as well as high apical calcium in a concentration-dependent manner [84]. As mentioned earlier, CaSR on both apical and basolateral membrane of the enterocytes have a role in the monitoring of calcium transport across the enterocytes. It was interesting to note that activation of CaSR led to FGF-23 production and suppression of calcium transport. Although the exact molecular mechanism and signaling pathway by which FGF-23 reduces the calcium transport remains elusive, several signaling proteins, such as MAPK/ ERK, p38 MAPK, and PKC might be involved in the process [53, 54].

FGF-23 production is not only stimulated by $1,25(\mathrm{OH})_{2} \mathrm{D}_{3}$, it is also enhanced by other calciotropic hormones, such as prolactin [105]. In mammalian, prolactin is known as a milk-producing hormone that acts as a major calcium-regulating hormone during pregnancy and lactation, the reproductive periods of high calcium demand [15]. Since prolactin markedly stimulates the transcellular and solvent drag-induced paracellular calcium absorption across the intestinal epithelium $[48,91]$, the local production of FGF23 may be a counterregulatory mechanism to restrict excessive calcium absorption during these reproductive periods.

\section{Stanniocalcin}

Previously recognized as a hypocalcemic hormone from the corpuscles of Stannius in osteichthyan fish, stanniocalcin-1 was also identified in the kidney of several mammal species, including rodent, cow, and human [44, 45, 99]. Regulation of stanniocalcin production and release in mammals remain elusive, but $1,25(\mathrm{OH})_{2} \mathrm{D}_{3}$ may be a part of its regulatory loop [44], similar to the negative feedback loop of FGF23. In opossum kidney proximal tubular cells, $1,25(\mathrm{OH})_{2} \mathrm{D}_{3}$ exposure was found to enhance stanniocalcin expression in a dose-dependent manner [42, 44]. Once released from the kidney, the circulating stanniocalcin is thought to activate its receptor on the basolateral membrane, but not the apical membrane, of enterocytes, to enhance the intestinal phosphate absorption, while suppressing calcium absorption [45, 65]. In the gut, stanniocalcin has been reported to express in stomach, small intestine, and colon of neonatal and mature rats [55]. Functional study by Madsen and colleagues reported the negative effect of stanniocalcin- 1 on net calcium absorption across the swine duodenum, consistent with its hypocalcemic action observed in fish [65].

Furthermore, stanniocalcin-1 not only functions as an endocrine factor but is also produced locally in the intestine to control calcium absorption. Xiang et al. [107] demonstrated in intestinal epithelium-like Caco-2 cells that overexpression of stanniocalcin- 1 could downregulate TRPV 5 and TRPV6 protein expression, suggesting that stanniocalcin-1-as a paracrine/autocrine factor-might directly and locally fine-tune calcium flux across the intestinal epithelium. Exposure to recombinant stanniocalcin-1 also directly suppressed TRPV5 and TRPV6 expression in stanniocalcin-1-knockdown Caco-2 cell without having an effect on PMCA ${ }_{1 b}$, NCX1, or VDR expression [107]. Although stanniocalcin-2 with $\sim 80 \%$ homology to stanniocalcin-1 has been identified in mammals, it is unclear whether this peptide can locally modulate intestinal calcium absorption. 


\section{Neural regulation of calcium transport}

Enterocytes are innervated by neurons from myenteric and submucosal plexuses in the enteric nervous system (ENS), which are in turn controlled by the autonomic neurons from both sympathetic and parasympathetic systems [67]. The ENS secretomotor neurons release a number of neurotransmitters [67], such as serotonin, galanin, neuropeptide $\mathrm{Y}$, acetylcholine, and vasoactive intestinal peptide (VIP), the last of which was found to modulate calcium absorption. However, there were few investigations regarding possible neural control on calcium absorption. An in vitro study in Caco-2 and HT29.19A monolayers reported that transcellular calcium uptake was increased by carbachol (a cholinomimetic drug) and VIP, whereas paracellular calcium transport was decreased by VIP [6]. In vivo study in rats supported the possibility of this neural control of calcium absorption since blockage of neural transmission by a potent voltage-dependent $\mathrm{Na}^{+}$channel inhibitor, tetrodotoxin (TTX), diminished the leucineinduced transcellular calcium transport (Thammayon, and Charoenphandhu, unpublished observation). Indeed, the sympathetic and VIP-ergic neurons may be essential for calcium and anion transport in other organs, e.g., the feline gallbladder mucosa. It was evident that noradrenergic stimulation enhanced net absorption of calcium, bicarbonate, and water, whereas VIP induced an opposite response [73]. Therefore, it is possible that neurons could regulate intestinal calcium absorption. However, more investigation is required to demonstrate how ENS controls the intestinal calcium transport as well as the final outcome(s) when multiple types of neurotransmitters are simultaneously released from the ENS neurons.

\section{Perspective and concluding remarks}

We have elaborated herein that to maintain appropriate calcium balance besides being stimulated by the well established PTH-1,25(OH $)_{2} \mathrm{D}_{3}$ hormonal axis, calcium transport across the intestinal epithelium can be restricted by a number of mechanisms. At the molecular level, when calcium concentration reaches a certain threshold level, binding of calcium ions to calcium-transporting proteins, channels, or tight junction proteins can inactivate these transporters and diminish transcellular and paracellular calcium transport [23, 52, 62]. Enterocytes also express CaSR, which detects free-ionized calcium on both luminal and pericellular vicinity, thereby initiating various cellular responses, including inhibition of calcium absorption [23, 62]. Furthermore, there are certain molecules such as FGF-23 that is produced by the enterocytes and negatively control calcium absorption in a paracrine/autocrine manner. Specifically, bone-derived FGF-23 is probably an important part of the negative feedback loop, as depicted in Fig. 1, to help prevent excess calcium input or calcium overload. Nevertheless, our knowledge on the negative regulators and their actions in the maintenance of calcium homeostasis is far from adequate, especially at organ level. For instance, the cellular and molecular mechanism(s) for local and systemic FGF-23 actions in the feedback regulation of calcium absorption are not completely understood, neither its contribution to body calcium homeostasis. Nevertheless, most investigations are from the large intestine, therefore, more investigations are required for the small intestine in order to confirm its physiological significance. Moreover, most reports were from animal study, therefore its role in human is worth exploring.

Besides the humoral factors, luminal factors, particularly iron and negatively charged molecules, can also hinder calcium absorption. For example, when iron absorption is upregulated, calcium absorption is suppressed presumably as result of ironinduced oxidative stress and inhibition of vesicular calcium transport [25, 58]. Meanwhile, negatively charged molecules, e.g., phytate and oxalate, are able to physically trap calcium in the lumen, thus reducing calcium uptake. Since it is possible to alter the luminal content in the intestine by dietary manipulation, better understanding of how luminal factors and nutrients fine-tune or interfere with calcium absorption would provide a strong foundation for dietary recommendation and further development of safe and effective calcium-fortified products for calcium-deficient osteoporotic patients and those with high calcium demand, such as pregnant and lactating mothers.

Funding This work was supported by grants from Mahidol University (to NC), the Thailand Research Fund (TRF) through the TRF Senior Research Scholar Grant (RTA6080007 to NC), the Faculty of Science, Mahidol University (to NC), TRF International Research Network Program (IRN60W0001 to KW and NC), Research Grant for New Scholar from TRF and Office of the Higher Education Commission (MRG6280198 to JT), and TRF through the Royal Golden Jubilee Ph.D. Program (PHD/0105/2557 to MR).

\section{Compliance with ethical standards}

Conflict of interest The authors declare that they have no conflicts of interest.

Ethical approval This article does not contain any studies with human participants or animals performed by any of the authors. 


\section{References}

1. Abrams SA, Griffin IJ, Davila PM (2002) Calcium and zinc absorption from lactose-containing and lactose-free infant formulas. Am J Clin Nutr 76:442-446

2. Amalraj A, Pius A (2015) Bioavailability of calcium and its absorption inhibitors in raw and cooked green leafy vegetables commonly consumed in India: an in vitro study. Food Chem $170: 430-436$

3. Armbrecht HJ, Zenser TV, Gross CJ, Davis BB (1980) Adaptation to dietary calcium and phosphorus restriction changes with age in the rat. Am J Physiol 239:E322-E327

4. Benn BS, Ajibade D, Porta A, Dhawan P, Hediger M, Peng JB, Jiang Y, Oh GT, Jeung EB, Lieben L, Bouillon R, Carmeliet G, Christakos S (2008) Active intestinal calcium transport in the absence of transient receptor potential vanilloid type 6 and calbindin- $\mathrm{D}_{9 \mathrm{k}}$. Endocrinology 149:3196-3205

5. Binder HJ, Singh SK, Geibel JP, Rajendran VM (1997) Novel transport properties of colonic crypt cells: fluid absorption and Cl-dependent Na-H exchange. Comp Biochem Physiol A Physiol 118:265-269

6. Blais A, Aymard P, Lacour B (1997) Paracellular calcium transport across Caco-2 and HT29 cell monolayers. Pflugers Arch 434:300-305

7. Bronner F (2003) Mechanisms of intestinal calcium absorption. J Cell Biochem 88:387-393

8. Brown AJ, Krits I, Armbrecht HJ (2005) Effect of age, vitamin D, and calcium on the regulation of rat intestinal epithelial calcium channels. Arch Biochem Biophys 437:51-58

9. Brun L, Brance M, Rigalli A (2012) Luminal calcium concentration controls intestinal calcium absorption by modification of intestinal alkaline phosphatase activity. Br J Nutr 108:229-233

10. Centeno VA, Díaz de Barboza GE, Marchionatti AM, Alisio AE, Dallorso ME, Nasif R, Tolosa de Talamoni NG (2004) Dietary calcium deficiency increases $\mathrm{Ca}^{2+}$ uptake and $\mathrm{Ca}^{2+}$ extrusion mechanisms in chick enterocytes. Comp Biochem Physiol A Mol Integr Physiol 139:133-141

11. Centeno V, Picotto G, Perez A, Alisio A, Tolosa de Talamoni N (2011) Intestinal $\mathrm{Na}^{+} / \mathrm{Ca}^{2+}$ exchanger protein and gene expression are regulated by $1,25(\mathrm{OH})_{2} \mathrm{D}_{3}$ in vitamin $\mathrm{D}$-deficient chicks. Arch Biochem Biophys 509:191-196

12. Chang W, Shoback D (2004) Extracellular $\mathrm{Ca}^{2+}$-sensing receptors: an overview. Cell Calcium 35:183-196

13. Charoenphandhu N, Krishnamra N (2007) Prolactin is an important regulator of intestinal calcium transport. Can J Physiol Pharmacol 85:569-581

14. Charoenphandhu N, Nakkrasae LI, Kraidith K, Teerapornpuntakit J, Thongchote K, Thongon N, Krishnamra N (2009) Twostep stimulation of intestinal $\mathrm{Ca}^{2+}$ absorption during lactation by long-term prolactin exposure and suckling-induced prolactin surge. Am J Physiol Endocrinol Metab 297:E609-E619

15. Charoenphandhu N, Wongdee K, Krishnamra N (2010) Is prolactin the cardinal calciotropic maternal hormone? Trends Endocrinol Metab 21:395-401

16. Charoenphandhu N, Laohapitakworn S, Kraidith K, Nakkrasae LI, Jongwattanapisan P, Tharabenjasin P, Krishnamra N (2011) Electrogenic $\mathrm{Na}^{+} / \mathrm{HCO}_{3}{ }^{-}$co-transporter-1 is essential for the parathyroid hormone-stimulated intestinal $\mathrm{HCO}_{3}{ }^{-}$secretion. Biochem Biophys Res Commun 409:775-779

17. Chattopadhyay N, Cheng I, Rogers K, Riccardi D, Hall A, Diaz R, Hebert SC, Soybel DI, Brown EM (1998) Identification and localization of extracellular $\mathrm{Ca}^{2+}$-sensing receptor in rat intestine. Am J Physiol 274:G122-G130

18. Cheng SX, Okuda M, Hall AE, Geibel JP, Hebert SC (2002) Expression of calcium-sensing receptor in rat colonic epithelium: evidence for modulation of fluid secretion. Am J Physiol Gastrointest Liver Physiol 283:G240-G250

19. Cheng SX, Lightfoot YL, Yang T, Zadeh M, Tang L, Sahay B, Wang GP, Owen JL, Mohamadzadeh M (2014) Epithelial CaSR deficiency alters intestinal integrity and promotes proinflammatory immune responses. FEBS Lett 588:4158-4166

20. Christakos S (2012) Mechanism of action of 1,25-dihydroxyvitamin $\mathrm{D}_{3}$ on intestinal calcium absorption. Rev Endocr Metab Disord 13:39-44

21. Colegio OR, Van Itallie C, Rahner C, Anderson JM (2003) Claudin extracellular domains determine paracellular charge selectivity and resistance but not tight junction fibril architecture. Am J Physiol Cell Physiol 284:C1346-C1354

22. Cook AE, Mistry SN, Gregory KJ, Furness SG, Sexton PM, Scammells PJ, Conigrave AD, Christopoulos A, Leach K (2015) Biased allosteric modulation at the $\mathrm{CaS}$ receptor engendered by structurally diverse calcimimetics. Br J Pharmacol 172:185-200

23. Derler I, Hofbauer M, Kahr H, Fritsch R, Muik M, Kepplinger K, Hack ME, Moritz S, Schindl R, Groschner K, Romanin C (2006) Dynamic but not constitutive association of calmodulin with rat TRPV6 channels enables fine tuning of $\mathrm{Ca}^{2+}$-dependent inactivation. J Physiol 577:31-44

24. Diaz de Barboza G, Guizzardi S, Tolosa de Talamoni N (2015) Molecular aspects of intestinal calcium absorption. World J Gastroenterol 21:7142-7154

25. Diaz de Barboza G, Guizzardi S, Moine L, Tolosa de Talamoni N (2017) Oxidative stress, antioxidants and intestinal calcium absorption. World J Gastroenterol 23:2841-2853

26. Doroudi M, Schwartz Z, Boyan BD (2015) Membrane-mediated actions of 1,25-dihydroxy vitamin $\mathrm{D}_{3}$ : a review of the roles of phospholipase $\mathrm{A}_{2}$ activating protein and $\mathrm{Ca}^{2+} /$ calmodulin-dependent protein kinase II. J Steroid Biochem Mol Biol 147:81-84

27. Douard V, Asgerally A, Sabbagh Y, Sugiura S, Shapses SA, Casirola D, Ferraris RP (2010) Dietary fructose inhibits intestinal calcium absorption and induces vitamin D insufficiency in CKD. J Am Soc Nephrol 21:261-271

28. Douard V, Sabbagh Y, Lee J, Patel C, Kemp FW, Bogden JD, Lin S, Ferraris RP (2013) Excessive fructose intake causes $1,25-(\mathrm{OH})_{2} \mathrm{D}_{3}$-dependent inhibition of intestinal and renal calcium transport in growing rats. Am J Physiol Endocrinol Metab 304:E1303-E1313

29. Fleet JC (2004) Rapid, membrane-initiated actions of 1,25 dihydroxyvitamin D: what are they and what do they mean? J Nutr 134:3215-3218

30. Fleet JC, Schoch RD (2010) Molecular mechanisms for regulation of intestinal calcium absorption by vitamin $\mathrm{D}$ and other factors. Crit Rev Clin Lab Sci 47:181-195

31. Fordtran JS, Locklear TW (1966) Ionic constituents and osmolality of gastric and small-intestinal fluids after eating. Am J Dig Dis 11:503-521

32. Fujita H, Sugimoto K, Inatomi S, Maeda T, Osanai M, Uchiyama Y, Yamamoto Y, Wada T, Kojima T, Yokozaki H, Yamashita T, Kato S, Sawada N, Chiba H (2008) Tight junction proteins claudin-2 and -12 are critical for vitamin D-dependent $\mathrm{Ca}^{2+}$ absorption between enterocytes. Mol Biol Cell 19:1912-1921

33. Gattineni J, Bates C, Twombley K, Dwarakanath V, Robinson ML, Goetz R, Mohammadi M, Baum M (2009) FGF23 decreases renal $\mathrm{NaPi}-2 \mathrm{a}$ and $\mathrm{NaPi}-2 \mathrm{c}$ expression and induces hypophosphatemia in vivo predominantly via FGF receptor 1 . Am J Physiol Renal Physiol 297:F282-F291

34. Gattineni J, Alphonse P, Zhang Q, Mathews N, Bates CM, Baum M (2014) Regulation of renal phosphate transport by FGF23 is mediated by FGFR1 and FGFR4. Am J Physiol Renal Physiol 306:F351-F358 
35. Geibel J, Sritharan K, Geibel R, Geibel P, Persing JS, Seeger A, Roepke TK, Deichstetter M, Prinz C, Cheng SX, Martin D, Hebert SC (2006) Calcium-sensing receptor abrogates secretagogue-induced increases in intestinal net fluid secretion by enhancing cyclic nucleotide destruction. Proc Natl Acad Sci USA 103:9390-9397

36. Gentili C, Morelli S, de Boland AR (2003) Characterization of $\mathrm{PTH} / \mathrm{PTHrP}$ receptor in rat duodenum: effects of ageing. J Cell Biochem 88:1157-1167

37. Goltzman D (2018) Physiology of parathyroid hormone. Endocrinol Metab Clin North Am 47:743-758

38. Gulec S, Anderson GJ, Collins JF (2014) Mechanistic and regulatory aspects of intestinal iron absorption. Am J Physiol Gastrointest Liver Physiol 307:G397-G409

39. Guo YC, Yuan Q (2015) Fibroblast growth factor 23 and bone mineralisation. Int J Oral Sci 7:8-13

40. Haussler MR, Jurutka PW, Mizwicki M, Norman AW (2011) Vitamin D receptor (VDR)-mediated actions of $1 \alpha, 25(\mathrm{OH})_{2}$ vitamin $\mathrm{D}_{3}$ : genomic and non-genomic mechanisms. Best Pract Res Clin Endocrinol Metab 25:543-559

41. Hebert SC, Cheng S, Geibel J (2004) Functions and roles of the extracellular $\mathrm{Ca}^{2+}$-sensing receptor in the gastrointestinal tract. Cell Calcium 35:239-247

42. Honda S, Kashiwagi M, Ookata K, Tojo A, Hirose S (1999) Regulation by $1 \alpha, 25$-dihydroxyvitamin $\mathrm{D}_{3}$ of expression of stanniocalcin messages in the rat kidney and ovary. FEBS Lett 459:119-122

43. Houston J, Smith K, Isakova T, Sowden N, Wolf M, Gutierrez OM (2013) Associations of dietary phosphorus intake, urinary phosphate excretion, and fibroblast growth factor 23 with vascular stiffness in chronic kidney disease. J Ren Nutr 23:12-20

44. Hung NT, Yamamoto H, Takei Y, Masuda M, Otani A, Kozai M, Ikeda S, Nakahashi O, Tanaka S, Taketani Y, Takeda E (2012) Up-regulation of stanniocalcin 1 expression by 1,25-dihydroxy vitamin $\mathrm{D}_{3}$ and parathyroid hormone in renal proximal tubular cells. J Clin Biochem Nutr 50:227-233

45. Ishibashi K, Imai M (2002) Prospect of a stanniocalcin endocrine/paracrine system in mammals. Am J Physiol Renal Physiol 282:F367-F375

46. Ishizawa M, Akagi D, Makishima M (2018) Lithocholic acid is a vitamin $\mathrm{D}$ receptor ligand that acts preferentially in the ileum. Int J Mol Sci 19:1975

47. Jando J, Camargo SMR, Herzog B, Verrey F (2017) Expression and regulation of the neutral amino acid transporter $\mathrm{B}^{0} \mathrm{AT} 1$ in rat small intestine. PLoS One 12:e0184845

48. Jantarajit W, Thongon N, Pandaranandaka J, Teerapornpuntakit J, Krishnamra N, Charoenphandhu N (2007) Prolactin-stimulated transepithelial calcium transport in duodenum and Caco-2 monolayer are mediated by the phosphoinositide 3-kinase pathway. Am J Physiol Endocrinol Metab 293:E372-E384

49. Jimbo R, Kawakami-Mori F, Mu S, Hirohama D, Majtan B, Shimizu Y, Yatomi Y, Fukumoto S, Fujita T, Shimosawa T (2014) Fibroblast growth factor 23 accelerates phosphateinduced vascular calcification in the absence of klotho deficiency. Kidney Int 85:1103-1111

50. Jongwattanapisan P, Suntornsaratoon P, Wongdee K, Dorkkam N, Krishnamra N, Charoenphandhu N (2012) Impaired body calcium metabolism with low bone density and compensatory colonic calcium absorption in cecectomized rats. Am J Physiol Endocrinol Metab 302:E852-E863

51. Jüppner H (2011) Phosphate and FGF-23. Kidney Int 79:S24-S27

52. Kellett GL (2011) Alternative perspective on intestinal calcium absorption: proposed complementary actions of $\mathrm{Ca}_{\mathrm{v}} 1.3$ and TRPV6. Nutr Rev 69:347-370

53. Khuituan P, Teerapornpuntakit J, Wongdee K, Suntornsaratoon P, Konthapakdee N, Sangsaksri J, Sripong C, Krishnamra
N, Charoenphandhu N (2012) Fibroblast growth factor-23 abolishes 1,25-dihydroxyvitamin $\mathrm{D}_{3}$-enhanced duodenal calcium transport in male mice. Am J Physiol Endocrinol Metab 302:E903-E913

54. Khuituan P, Wongdee K, Jantarajit W, Suntornsaratoon P, Krishnamra N, Charoenphandhu N (2013) Fibroblast growth factor-23 negates $1,25(\mathrm{OH})_{2} \mathrm{D}_{3}$-induced intestinal calcium transport by reducing the transcellular and paracellular calcium fluxes. Arch Biochem Biophys 536:46-52

55. Kobayashi R, Nakagomi Y, Shimura Y, Mochizuki M, Kobayashi K, Sugita K, Ohyama K (2009) Expression of stanniocalcin-1 in gastrointestinal tracts of neonatal and mature rats. Biochem Biophys Res Commun 389:478-483

56. Kolek OI, Hines ER, Jones MD, LeSueur LK, Lipko MA, Kiela PR, Collins JF, Haussler MR, Ghishan FK (2005) 1 $\alpha, 25$ dihydroxyvitamin $\mathrm{D}_{3}$ upregulates FGF23 gene expression in bone: the final link in a renal-gastrointestinal-skeletal axis that controls phosphate transport. Am J Physiol Gastrointest Liver Physiol 289:G1036-G1042

57. Kopic S, Geibel JP (2013) Gastric acid, calcium absorption, and their impact on bone health. Physiol Rev 93:189-268

58. Kraidith K, Svasti S, Teerapornpuntakit J, Vadolas J, Chaimana R, Lapmanee S, Suntornsaratoon P, Krishnamra N, Fucharoen $\mathrm{S}$, Charoenphandhu N (2016) Hepcidin and $1,25(\mathrm{OH})_{2} \mathrm{D}_{3}$ effectively restore $\mathrm{Ca}^{2+}$ transport in $\beta$-thalassemic mice: reciprocal phenomenon of $\mathrm{Fe}^{2+}$ and $\mathrm{Ca}^{2+}$ absorption. Am J Physiol Endocrinol Metab 311:E214-E223

59. Kumar V, Abbas AK, Aster JC (2015) Cellular responses to stress and toxic insults: adaptation, injury, and death. In: Kumar V, Abbas AK, Aster JC (eds) Robbins and Cotran pathologic basis of disease, 9th edn. Elsevier Saunders, Philadelphia, pp 31-68

60. Lamireau T, Zoltowska M, Levy E, Yousef I, Rosenbaum J, Tuchweber B, Desmouliere A (2003) Effects of bile acids on biliary epithelial cells: proliferation, cytotoxicity, and cytokine secretion. Life Sci 72:1401-1411

61. Laohapitakworn S, Thongbunchoo J, Nakkrasae LI, Krishnamra $\mathrm{N}$, Charoenphandhu N (2011) Parathyroid hormone (PTH) rapidly enhances CFTR-mediated $\mathrm{HCO}_{3}{ }^{-}$secretion in intestinal epithelium-like Caco-2 monolayer: a novel ion regulatory action of PTH. Am J Physiol Cell Physiol 301:C137-C149

62. Lee D, Obukhov AG, Shen Q, Liu Y, Dhawan P, Nowycky MC, Christakos S (2006) Calbindin- $\mathrm{D}_{28 \mathrm{k}}$ decreases L-type calcium channel activity and modulates intracellular calcium homeostasis in response to $\mathrm{K}^{+}$depolarization in a rat beta cell line RINr104638. Cell Calcium 39:475-485

63. Lertsuwan K, Wongdee K, Teerapornpuntakit J, Charoenphandhu $\mathrm{N}$ (2018) Intestinal calcium transport and its regulation in thalassemia: interaction between calcium and iron metabolism. J Physiol Sci 68:221-232

64. Liu S, Tang W, Zhou J, Stubbs JR, Luo Q, Pi M, Quarles LD (2006) Fibroblast growth factor 23 is a counter-regulatory phosphaturic hormone for vitamin D. J Am Soc Nephrol 17:1305-1315

65. Madsen KL, Tavernini MM, Yachimec C, Mendrick DL, Alfonso PJ, Buergin M, Olsen HS, Antonaccio MJ, Thomson AB, Fedorak RN (1998) Stanniocalcin: a novel protein regulating calcium and phosphate transport across mammalian intestine. Am J Physiol 274:G96-G102

66. Marchionatti A, Rivoira M, Rodriguez V, Perez A, Tolosa de Talamoni N (2018) Molecular mechanisms triggered by bile acids on intestinal $\mathrm{Ca}^{2+}$ absorption. Curr Med Chem 25:2122-2132

67. Mittal R, Debs LH, Patel AP, Nguyen D, Patel K, O'Connor G, Grati M, Mittal J, Yan D, Eshraghi AA, Deo SK, Daunert S, Liu XZ (2017) Neurotransmitters: the critical modulators regulating gut-brain axis. J Cell Physiol 232:2359-2372 
68. Morgan EL, Mace OJ, Affleck J, Kellett GL (2007) Apical GLUT2 and $\mathrm{Ca}_{\mathrm{v}}$ 1.3: regulation of rat intestinal glucose and calcium absorption. J Physiol 580:593-604

69. Mosha TC, Gaga HE, Pace RD, Laswai HS, Mtebe K (1995) Effect of blanching on the content of antinutritional factors in selected vegetables. Plant Foods Hum Nutr 47:361-367

70. Murgue B, Tsunekawa S, Rosenberg I, deBeaumont M, Podolsky DK (1994) Identification of a novel variant form of fibroblast growth factor receptor 3 (FGFR3 IIIb) in human colonic epithelium. Cancer Res 54:5206-5211

71. Nemere I, Norman AW (1986) Parathyroid hormone stimulates calcium transport in perfused duodena from normal chicks: comparison with the rapid (transcaltachic) effect of 1,25-dihydroxyvitamin $\mathrm{D}_{3}$. Endocrinology 119:1406-1408

72. Nemere I, Garbi N, Hammerling GJ, Khanal RC (2010) Intestinal cell calcium uptake and the targeted knockout of the $1,25 \mathrm{D}_{3}$ MARRS (membrane-associated, rapid response steroid-binding) receptor/PDIA3/Erp57. J Biol Chem 285:31859-31866

73. Nilsson B, Delbro D, Friman S, Thune A, Svanvik J (1996) Sympathetic and VIP-ergic control of calcium and bicarbonate transport in the feline gall bladder mucosa in vivo. J Auton Nerv Syst 60:49-55

74. Noonan WT, Woo AL, Nieman ML, Prasad V, Schultheis PJ, Shull GE, Lorenz JN (2005) Blood pressure maintenance in NHE3-deficient mice with transgenic expression of NHE3 in small intestine. Am J Physiol Regul Integr Comp Physiol 288:R685-R691

75. Norman AW (2006) Minireview: vitamin D receptor: new assignments for an already busy receptor. Endocrinology 147:5542-5548

76. O'Grady SM, Jiang X, Maniak PJ, Birmachu W, Scribner LR, Bulbulian B, Gullikson GW (2002) Cyclic AMP-dependent Cl secretion is regulated by multiple phosphodiesterase subtypes in human colonic epithelial cells. J Membr Biol 185:137-144

77. Owen JL, Cheng SX, Ge Y, Sahay B, Mohamadzadeh M (2016) The role of the calcium-sensing receptor in gastrointestinal inflammation. Semin Cell Dev Biol 49:44-51

78. Quarles LD (2012) Skeletal secretion of FGF-23 regulates phosphate and vitamin D metabolism. Nat Rev Endocrinol 8:276-286

79. Quinn SJ, Thomsen AR, Pang JL, Kantham L, Brauner-Osborne H, Pollak M, Goltzman D, Brown EM (2013) Interactions between calcium and phosphorus in the regulation of the production of fibroblast growth factor 23 in vivo. Am J Physiol Endocrinol Metab 304:E310-E320

80. Raschka L, Daniel H (2005) Mechanisms underlying the effects of inulin-type fructans on calcium absorption in the large intestine of rats. Bone 37:728-735

81. Rievaj J, Pan W, Cordat E, Alexander RT (2013) The $\mathrm{Na}^{+} / \mathrm{H}^{+}$ exchanger isoform 3 is required for active paracellular and transcellular $\mathrm{Ca}^{2+}$ transport across murine cecum. Am J Physiol Gastrointest Liver Physiol 305:G303-G313

82. Ritter CS, Haughey BH, Miller B, Brown AJ (2012) Differential gene expression by oxyphil and chief cells of human parathyroid glands. J Clin Endocrinol Metab 97:E1499-E1505

83. Rivoira MA, Marchionatti AM, Centeno VA, Díaz de Barboza GE, Peralta López ME, Tolosa de Talamoni NG (2012) Sodium deoxycholate inhibits chick duodenal calcium absorption through oxidative stress and apoptosis. Comp Biochem Physiol A Mol Integr Physiol 162:397-405

84. Rodrat M, Wongdee K, Panupinthu N, Thongbunchoo J, Teerapornpuntakit J, Krishnamra N, Charoenphandhu N (2018) Prolonged exposure to $1,25(\mathrm{OH})_{2} \mathrm{D}_{3}$ and high ionized calcium induces FGF-23 production in intestinal epithelium-like Caco-2 monolayer: a local negative feedback for preventing excessive calcium transport. Arch Biochem Biophys 640:10-16
85. Rodriguez V, Rivoira M, Guizzardi S, Tolosa de Talamoni N (2017) Naringin prevents the inhibition of intestinal $\mathrm{Ca}^{2+}$ absorption induced by a fructose rich diet. Arch Biochem Biophys 636:1-10

86. Schröder B, Schlumbohm C, Kaune R, Breves G (1996) Role of calbindin- $\mathrm{D}_{9 \mathrm{k}}$ in buffering cytosolic free $\mathrm{Ca}^{2+}$ ions in pig duodenal enterocytes. J Physiol 492:715-722

87. Schwartz Z, Graham EJ, Wang L, Lossdorfer S, Gay I, JohnsonPais TL, Carnes DL, Sylvia VL, Boyan BD (2005) Phospholipase $\mathrm{A}_{2}$ activating protein (PLAA) is required for $1 \alpha, 25(\mathrm{OH})_{2} \mathrm{D}_{3}$ signaling in growth plate chondrocytes. J Cell Physiol 203:54-70

88. Sharma V, O'Halloran DM (2014) Recent structural and functional insights into the family of sodium calcium exchangers. Genesis 52:93-109

89. Shimada T, Hasegawa H, Yamazaki Y, Muto T, Hino R, Takeuchi Y, Fujita T, Nakahara K, Fukumoto S, Yamashita T (2004) FGF23 is a potent regulator of vitamin D metabolism and phosphate homeostasis. J Bone Miner Res 19:429-435

90. Shimada T, Yamazaki Y, Takahashi M, Hasegawa H, Urakawa I, Oshima T, Ono K, Kakitani M, Tomizuka K, Fujita T, Fukumoto S, Yamashita T (2005) Vitamin D receptor-independent FGF23 actions in regulating phosphate and vitamin D metabolism. Am J Physiol Renal Physiol 289:F1088-F1095

91. Suntornsaratoon P, Kraidith K, Teerapornpuntakit J, Dorkkam N, Wongdee K, Krishnamra N, Charoenphandhu N (2014) Presuckling calcium supplementation effectively prevents lactationinduced osteopenia in rats. Am J Physiol Endocrinol Metab 306:E177-E188

92. Tahiri M, Tressol JC, Arnaud J, Bornet FR, Bouteloup-Demange C, Feillet-Coudray C, Brandolini M, Ducros V, Pepin D, Brouns F, Roussel AM, Rayssiguier Y, Coudray C (2003) Effect of shortchain fructooligosaccharides on intestinal calcium absorption and calcium status in postmenopausal women: a stable-isotope study. Am J Clin Nutr 77:449-457

93. Takaishi S, Sawada M, Morita Y, Seno H, Fukuzawa H, Chiba $\mathrm{T}$ (2000) Identification of a novel alternative splicing of human FGF receptor 4: soluble-form splice variant expressed in human gastrointestinal epithelial cells. Biochem Biophys Res Commun 267:658-662

94. Tang L, Cheng CY, Sun X, Pedicone AJ, Mohamadzadeh M, Cheng SX (2016) The extracellular calcium-sensing receptor in the intestine: evidence for regulation of colonic absorption, secretion, motility, and immunity. Front Physiol 7:245

95. Thacher TD, Aliu O, Griffin IJ, Pam SD, O’Brien KO, Imade GE, Abrams SA (2009) Meals and dephytinization affect calcium and zinc absorption in Nigerian children with rickets. J Nutr 139:926-932

96. Thammayon N, Wongdee K, Lertsuwan K, Suntornsaratoon P, Thongbunchoo J, Krishnamra N, Charoenphandhu N (2017) $\mathrm{Na}^{+} /$ $\mathrm{H}^{+}$exchanger 3 inhibitor diminishes the amino-acid-enhanced transepithelial calcium transport across the rat duodenum. Amino Acids 49:725-734

97. Thwaites DT, Anderson CM (2007) $\mathrm{H}^{+}$-coupled nutrient, micronutrient and drug transporters in the mammalian small intestine. Exp Physiol 92:603-619

98. Toka HR (2014) New functional aspects of the extracellular calcium-sensing receptor. Curr Opin Nephrol Hypertens 23:352-360

99. Tremblay G, Delbecchi L, Loiselle MC, Ster C, Wagner GF, Talbot BG, Lacasse P (2009) Serum levels of stanniocalcin-1 in Holstein heifers and cows. Domest Anim Endocrinol 36:105-109

100. Vervloet M (2019) Renal and extrarenal effects of fibroblast growth factor 23. Nat Rev Nephrol 15:109-120

101. Wagner CA (2013) The calcium-sensing receptor directly regulates proximal tubular functions. Kidney Int 84:228-230 
102. Wang CY, Liu S, Xie XN, Tan ZR (2017) Regulation profile of the intestinal peptide transporter 1 (PepT1). Drug Des Devel Ther 11:3511-3517

103. Wasserman RH (2004) Vitamin D and the dual processes of intestinal calcium absorption. J Nutr 134:3137-3139

104. Wongdee K, Charoenphandhu N (2015) Vitamin D-enhanced duodenal calcium transport. Vitam Horm 98:407-440

105. Wongdee K, Teerapornpuntakit J, Sripong C, Longkunan A, Chankamngoen W, Keadsai C, Kraidith K, Krishnamra N, Charoenphandhu N (2016) Intestinal mucosal changes and upregulated calcium transporter and FGF-23 expression during lactation: contribution of lactogenic hormone prolactin. Arch Biochem Biophys 590:109-117

106. Wongdee K, Krishnamra N, Charoenphandhu N (2017) Derangement of calcium metabolism in diabetes mellitus: negative outcome from the synergy between impaired bone turnover and intestinal calcium absorption. J Physiol Sci 67:71-81

107. Xiang J, Guo R, Wan C, Wu L, Yang S, Guo D (2016) Regulation of intestinal epithelial calcium transport proteins by stanniocalcin-1 in Caco2 cells. Int J Mol Sci 17:1095

108. Yanahira S, Morita M, Aoe S, Suguri T, Takada Y, Miura S, Nakajima I (1997) Effects of lactitol-oligosaccharides on calcium and magnesium absorption in rats. J Nutr Sci Vitaminol (Tokyo) 43:123-132
109. Younoszai MK, Nathan R (1985) Intestinal calcium absorption is enhanced by D-glucose in diabetic and control rats. Gastroenterology 88:933-938

110. Yu AS, Cheng MH, Angelow S, Gunzel D, Kanzawa SA, Schneeberger EE, Fromm M, Coalson RD (2009) Molecular basis for cation selectivity in claudin-2-based paracellular pores: identification of an electrostatic interaction site. J Gen Physiol 133:111-127

111. Zierold C, Mings JA, DeLuca HF (2003) Regulation of 25-hydroxyvitamin $\mathrm{D}_{3}$-24-hydroxylase mRNA by 1,25 -dihydroxyvitamin $\mathrm{D}_{3}$ and parathyroid hormone. J Cell Biochem 88:234-237

112. Zihni C, Mills C, Matter K, Balda MS (2016) Tight junctions: from simple barriers to multifunctional molecular gates. Nat Rev Mol Cell Biol 17:564-580

Publisher's Note Springer Nature remains neutral with regard to jurisdictional claims in published maps and institutional affiliations. 